\title{
Race, Religion, \& Anti-Poverty Policy Attitudes
}

\author{
RONALD E. BROWN \\ Department of Political Science \\ Wayne State University \\ Davin Phoenix \\ Department of Political Science \\ University of California at Irvine
}

\author{
R. KHARI BROWN \\ Department of Sociology \\ Wayne State University \\ James S. Jackson \\ Institute for Social Research \\ University of Michigan
}

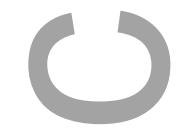

Using the 2008 National Politics Study, the present study indicates that while African Americans are more likely than Whites to hear sermons about poverty and other political issues, hearing such sermons more consistently associates with support for antipoverty government programs among Non-Hispanic Whites than among both African Americans and Hispanics. The racially/ ethnically marginalized status of Blacks and Hispanics may contribute to these groups being more receptive than Whites to religious messages emphasizing social inequality. The contrasting racial experiences of dominance and marginalization may also help explain why hearing politicized sermons are more meaningful to the progressive social welfare attitudes of Whites than to African Americans and Hispanics. This expectation is rooted in the heightened variability of perspectives among Whites and their religious organizations regarding the government's role in aiding the economically disadvantaged. Conversely, the vast majority of Blacks and Hispanics support the government helping individuals that have fallen upon hard times. The greater variability in opinion among Whites may also allow for greater differences in opinion to emerge between Whites that attend relative to those outside of religious congregations led by clergy

This is the author manuscript accepted for publication and has undergone full peer review but has not been through the copyediting, typesetting, pagination and proofreading process, which may lead to differences between this version and the Version of Record. Please cite this article as doi: $\underline{10.1111 / \text { jssr. } 12258 .}$.

This article is protected by copyright. All rights reserved. 
emphasizing spiritual and political solidarity with the poor than is the case for African Americans and Hispanics.

Keywords: Racelethnicity, social welfare, public opinion, sermons.

Correspondence should be addressed to R. Khari Brown, Department of Sociology, Wayne State University, 656 W. Kirby Street, Detroit, MI 48202 USA. Email: kharib@wayne.edu

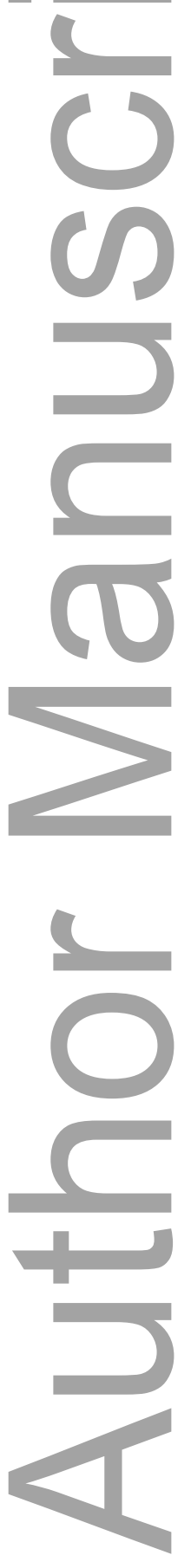




\section{INTRODUCTION}

One of the earliest American sermons about the duty and obligations of American Christians toward the poor can be found in John Winthrop's “A Model of Christian Charity," written in 1630 on board the Arbella, as the ship travelled from England toward the Salem Colony in Massachusetts. Winthrop maintained that "every man must have need of the other" because community bonding is enhanced when members provide assistance or help to those in want or distress (Winthrop 1999). There is a body of thought that the Puritans are the foundation of what Max Weber (2013) calls the "rational spirit of capitalism" that influences American attitudes about work, the underserving poor, and the responsibility of religious and government bodies toward the poor (Collins, 1996, Morone, 2003, Jones 2007). The rational spirit of capitalism ethos was challenged during the Progressive Era by Walter Rauschenbusch, a Baptist theologian and social activist, who argued that cutthroat capitalism was major cause of poverty and misery in American cities (1917). His words served as the catalyst for the formation of the Federal Council of Churches in 1908, renamed the National Council of Churches in 1950, which committed itself toward civic and political efforts aimed at improving working conditions in factories, worker's rights, and greater access to government social services and housing for the urban working poor (Bradley 2005, Morone, 2003).

The Social Gospel ethos of Raushenbusch and others like him that emerged during the Progressive Era of the early $20^{\text {th }}$ century continued to influence the sermonizing and activism of progressive religious organizations, clergy and laity throughout the $20^{\text {th }}$ and into the $21^{\text {st }}$ centuries (Slessarev-Jamir, 2011). Illustrative of such was the Poor People's Campaign, articulated by Martin Luther King, as president of the Southern Christian Leadership Conference (SCLC), in November 1967. The SCLC, with support from civil-religious political groups such as the National Council of Churches and the American Friends Service 
Committee, launched Resurrection City on May 21, 1968 (Poor People’s Campaign, 2014). Responding to King's call for solidarity with the poor, thousands of Americans constructed tents on the lawn of White House to symbolically exhibit the indescribable living situations daily endured by poor people. The Welfare Rights Movement of the late 1960s and early 1970s was an outgrowth of this Campaign (West, 1981). With early financial support and technical assistance from the National Council of Churches and U.S. Catholic Church, this movement attempted to mobilize poor women to push county and state governments to provide the social welfare services for which they qualified. Following the same model of grassroots mobilization, in the current era, congregants of the roughly 3,500 religious congregations affiliated with faith-based community organizing firms — such as the Industrial Areas Foundation-respond to sermons that encourage them to contact elected officials, attend public rallies, and, give speeches in support of legislation that would significantly improve the living conditions of the poor (Warren, 2001; Wood, 2002).

That said, the current study is principally interested in how exposure to sermons about poverty-related issues associate with beliefs about the government's role in assisting the poor. While pursuing this line of inquiry, we are quite cognizant that race, unfortunately, structures public sentiment about the responsibility of religious institutions and the government toward the poor. For White Americans, perceptions of food stamp programs, school lunch programs, and public housing or voucher programs associate with racial animus towards blacks: blacks, are lazy, lack ambition, and are therefore not deserving of governmental assistance (Bobo, 1988; Gilens, 1999; Kinder and Sanders 1996; Tarman and Sears, 2005). Along these lines, a number of scholars link the membership and financial declines in Mainline Protestant Churches during the 1970s to lay disagreements with their clergy taking progressive and public positions on racial inequality, poverty, and peace activism (Steensland, 2002; Verter, 2002; Wald \& Calhoun-Brown, 2010). We know too that, Blacks and Hispanics are over- 
represented and Whites under-represented in congregations involved in community organizing activities with and on behalf of the poor (Warren \& Wood, 2002). Given this reality, we are particularly interested in how race/ethnicity determines who attends worship settings in which they are exposed to sermons about poverty and related issues. We also examine racial differences in the association between hearing such sermons and social welfare policy attitudes. We utilize the 2008 National Politics Studies (NPS) to pursue these aims. 2008 is significant, as Barack Obama was elected President, the first African American to do so. In addition, in 2008 , the economy was the number one issue of concern to Americans as the nation was in the midst of its worst economic recession since the Great Depression (Pew, 2010). This is the context in which we pursue our research aims of the association between race/ethnicity, religion, and social welfare policy attitudes.

\section{Significance of Study}

Examining the relationships between race, exposure to sermon about poverty and inequality, as well as social welfare attitudes is worthwhile insofar a political sermon is the communication instrument by which clergy either seeks to persuade, reinforce a set of beliefs, or increase the knowledge base of congregants. And yet, we argue that on contentious issues, such as poverty, there is often a lack of consensus among people of faith about what they ought to do. Discussions aimed at either maintaining or increasing governmental budgetary outlays for the poor often run counter to the dominant American ethos that a rational capitalist order provides vast economic opportunities for mobility are available, provided citizens are willing to work (Kluegal, 1981). That said, recalling politicized sermons and having the opportunity to deliberate on such matters in places of worship may matter most when there is lack of consensus on the obligation of religious bodies or government towards stigmatized populations, such as the poor, particularly those on welfare (Neiheisel, Djupe, \& Sokhey, 2009). Such persuasive sermons may cause the listener 
to associate religious texts, sayings, and tenants to duties and obligations of the government toward the poor and marginalized (Harris, 1999). By examining the association between recalling sermons about poverty and related issues and support for government-based programs targeting the poor, we aim to increase our knowledge of the relative power of sermons to strengthen citizens' commitment to public policy solutions that promote the common good (Mendelberg \& Oleske, 2000).

As stated, local clergy are leaders of arguably the most influential American civil societal institution, based upon membership rates, volunteerism, and donations (Independent Sector, 2002). Nearly all worship-goers report trusting their fellow congregants, and Americans consistently rank religion as one of the top four institutions in which they hold confidence (Gallup, 2013; SCBS, 2000, 2014). The centrality of religion to many Americans may help explain why close to eighty percent say they want their religious institutions more active in politically advocating for the poor (Wuthnow, 2000). Close to half of Americans say they want religious leaders speaking out about the growing gap between the rich and the poor and the need to raise the minimum wage (PRRI, 2011). To the degree that clergy articulate the interest of the economically marginalized, and act as an "advocate and party to the causes" of the poor, they are indeed delivering messages that explicitly state the government has a moral and spiritual obligation to the poor and needy (Pitkin, 1967).

Finally, it is important to quantitatively examine the association between race, sermon exposure, and anti-poverty policy attitudes because it simply has not been done before. To be clear, the qualitative and archival work on religion and social justice activism provides vital data about the role of progressive religious leaders in constructing and reinforcing congregants' commitment to the poor and oppressed (Slessarev-Jamir, 2011; Warren, 2001; Wood, 2002). Nonetheless, it remains unclear if these findings apply only to their cases, or if they speak to the broader impact political sermons have on commitments to the poor. 
We know from prior survey-based investigations that while religious faith is largely unrelated to anti-poverty policy attitudes, worship attendance is associated with such views (Green, 2004; Pew, 2010; Wilson, 1999). That is, holding religious faith constant, the more often Americans attend worship services, the less likely they are to support government programs targeting the poor (Chen \& Lind, 2007). However, by failing to include measures on sermon exposure, these studies obscure potential distinctions among worship-goers that hear sermons about poverty and social inequality from those that do not. As stated earlier, the current study attempts to clarify the intersection between race/ethnicity, religion, and antipoverty attitudes by examining race/ethnic differences in exposure to sermons on poverty and other political issues. We also examine racial/ethnic differences in the association between recalling hearing these types of sermons and support for government programs targeting the economically disadvantaged.

\section{Why Does Race Matter?}

There is reason to believe that African Americans and Hispanics are more likely than Whites to attend congregations where they hear sermons about poverty and economic-related issues. Due in part, to their racially/ethnically marginalized status, Blacks and Hispanics are likely more receptive than Whites to religious messages emphasizing the wrongness of poverty and social inequality in such a wealthy nation. Indeed, Blacks and Hispanics are more supportive than Whites of religious congregations; taking stands on social-political issues (Green, 2004), being more active in politically advocating for the poor, and forming political movements (Wuthnow, 2000). Racial/ethnic minorities are also more supportive than Whites of their clergy talking about the growing gap between the rich and the poor (PRRI, 2011). Indeed, past research tells us that Black and Hispanic worship-goers are also more likely than Whites to be led by clergy that talk about social justice and are involved in local and regional community organizing efforts (Brown, 2009; Wood \& Warren, 2002). 
Moreover, it is reasonable to expect that Blacks and Hispanics are more likely than Whites to attend religious congregations where they hear sermons about poverty and other economicrelated issues.

That said, it is quite plausible that many sermons and lectures led by clergy and even lay testimonies about poverty-related concerns do not go beyond prayer requests and emotional support (Baer \& Singer, 2002). This is not to downplay the potential social and cultural capital within religious congregations to provide meaningful political cues that that signal a need for government intervention to address such concerns (Neiheisel, Djupe, \& Sokhey, 2009). Rather, as alluded to earlier, it is to say that religious bodies exist on a continuum stretching from a priestly orientation that tends to invest in individual spiritual or emotional well-being, to a prophetic orientation in which the religious body acts as a vehicle through which God brings about a more just society, particularly for the poor and powerless Lincoln \& Mamiya, 1990; Roozen, McKinney \& Carrol, 1984). Moreover, the extent to which exposure to social concerns in houses of worship stimulate calls for public policy intervention, these calls are likely framed as political matters that are consistent with the congregation's sense that human flourishing is only possible for the most vulnerable portions of the society if there is a governmental safety net. One way to measure the degree to which sermons/ lectures about poverty-related concerns contain cues about the necessity of public policy intervention is to examine the association between exposure to such sermons and attitudes about government intervention.

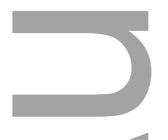

\section{Religion, Economics and Government}

Max Weber is perhaps the first sociologist to have recognized the potential of religious teachings to shape patterns of economic orientations and behavior. Weber (2013) argues that religion principally influenced society through its ideas and doctrines. That is, in addition to religious teachings providing members of social groups a means to understand the 
world around them, it also provided an ethos: a core of group-based ideals that helps frame experiences and ultimately shape attitudes and behaviors. In The Protestant Ethic and the Spirit of Capitalism, he maintained that the emergence of a Western European capitalists ethos that emphasized hard work as an end itself and wealth as a sign of ones' pious investment, was inspired by the $16^{\text {th }}$ century teachings of Martin Luther and John Calvin and their clerical followers in subsequent centuries (Jones, 2007; Weber, 2013). For Weber, Western European adherence to Lutheran and Calvinist teachings was an important factor among many that contributed to a capitalist ethos. If we accept Weber's thesis that religious teachings matter to economic attitude formation, it is plausible that hearing sermons about poverty-related concerns may shape and/or reinforce how Americans think about poverty and the government's response to this social problem.

We may also expect religious teaching to associate with political attitudes because, as Durkheim posits in his seminal piece, the Elementary Forms of Religion (1995), religion is the basis of social group identity because it imbeds varying totemic objects with sacred meanings. The shared meaning of these symbols provides a common understanding of individual experiences. In recognizing their shared commonality, these symbols serve as reminders of how individuals should relate to one another in effort to preserve and further the group's common good. Similarly, Geertz (1977) argues that religion provides a worldview through which community members makes sense of their reality and experiences. This worldview is essential to a religious ethos that motivates group members to act ethically toward fellow group members. Religious rituals reaffirm the relevance of group based worldviews as a means to interpret and respond to one's reality (Geertz (1977). Indeed, Geertz (1977) maintains that cultural performances, which, for our purposes, include sermons, seek to reinforce a common understanding and appropriate response to experiences through the use of culturally relevant symbols. That said, it is understandable that a number 
of studies point to the importance of clergy and lay leaders in informing political attitudes and behaviors (Brown, 2003; 2011; Djupe \& Gilbert, 2008; Neiheisel, Djupe \& Sokhey, 2009).

We know from past historical and survey-based studies that clergy with a liberal theology and political ideology are considerably more likely than are their conservative peers to speak out about poverty, militarism, and racism (Neuhaus, 1970; Putnam, Sanders, \& Campbell, 2011; Quinley, 1974). In doing so, religious leaders of progressive congregations attempt to heighten identification with the poor among their congregants and, as was the case with King (1967), demand that governments do more to address the vexing problems confronting the black poor. These clergy also attempt to convey the potential unhappiness, anxiety, and loss of hope among the poor, while drawing upon a tradition of Christian liberalism that asserts that their followers, at a minimum, must see the plight of the poor as a central concern (Bellah, 1975; Slessarev-Jamir, 2011). In many cases, these clergy promote a congregational culture that encourages and provides space for deliberation about their obligation to the poor and other groups suffering from oppression and blocked opportunities (Neiheisel, Djupe \& Sokhey, 2009). Congregants that accept such sermonic signaling may hold the opinion that America's exceptional material blessing requires that the church, as a sociological body, and individuals engage in actions, or, at a minimum, support public policies targeting the poor (Bellah, 1975). That said we are particularly interested in how race impacts the salience of hearing poverty-related sermons to American social welfare policy attitudes.

\section{Race, Sermons \& Policy Attitudes}

There is a considerable amount of research that indicates that political cues matter to electoral, political campaign, and protest behavior (Brown \& Brown, 2003; Brown, 2010; Djupe \& Gilbert, 2008). However, as stated earlier, there is relatively little research on the 
association between exposure to sermons / political discussions within houses of worship and public policy attitudes. The existing work in this area largely suggests that political cues from clergy and/or congregants can inform public policy attitudes (Brown, Brown, \& Blase, 2013; Brown, Kaiser \& Jackson, 2014; Djupe \& Gilbert, 2008). That said, we have reason to believe that exposure to such cues may have a greater tendency to signal the need for governmental response when heard among Whites than among Blacks and Hispanics.

The greater variability of perspectives among Whites, relative to Blacks and Hispanics, regarding the government's role in aiding the economically disadvantaged may lend exposure to sermons about poverty-related concerns maintaining a stronger association with White social welfare attitudes than among Blacks and Hispanics. For example, whereas eight in ten Blacks and Hispanics believe that the government should "guarantee every citizen enough to eat and a place to sleep," roughly half of Whites hold this view (Kohut et. al., 2012,pg. 32)." To be clear, it is quite likely that African American and Hispanics that chose and continue to attend congregations where they hear sermons emphasizing political advocacy with and on behalf of the poor tend to agree with such messaging. However, that these groups maintain such high levels of support for government intervention on behalf of the poor may contribute to the minimal difference in attitudes among those within and outside of progressive worship spaces. In effect, the views of Blacks and Hispanics on the antecedents and solutions for poverty and inequality are likely robust to the types of messaging they receive in their places of worship. As a result, empirical examinations of the linkage between exposure to sermons on poverty and political views on poverty among Blacks and Hispanics may yield only weak or non-associations. In contrast, the greater level of contention among Whites on the causes of social inequality and poverty may mean that poverty-related sermons have a greater chance of associating with their opinions on the most effective means of addressing these issues. 
Subsequently, we fully expect that Blacks and Hispanics are more likely than Whites to attend religious settings in which discussions about poverty take place. However, in the event that Blacks, Whites, and Hispanics are exposed to such discussions, there is likely a greater chance that these discussion lead to calls for policy intervention among Whites than among African Americans and Hispanics. This leads to our hypotheses;

\section{Hypotheses}

1. African Americans are more likely than Non-Hispanic Whites to attend worship services where they hear sermons about economic-related issues.

2. The association between exposure to sermons on poverty and social welfare attitudes is stronger among Non-Hispanic Whites than among both African Americans and Hispanic Americans.

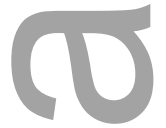

\section{Sample}

This study relies upon the 2008 National Politics Studies (NPS), which are based upon a national sample of individuals, aged 18 years or older. Interviews occurred throughout the United States in urban and rural centers of the country where significant numbers of African Americans reside. A total of 1,477 Americans were interviewed, 519 of whom are Non-Hispanic White Americans, 444 of whom are Hispanic Americans, 329 of whom are African American, with the remainder being of other racial/ethnic groups. The current study, however, is restricted to the Non-Hispanic White, Hispanic, and African American samples. The Survey Research Center Division within a Research Institute of a Midwestern public university went into the field in September of 2008 and concluded in February of 2009. All of the interviews were conducted over the telephone in either English or Spanish, depending on the preference of the respondent. The overall response rate was 41\%. A more detailed description of the study is provided by Jackson et. al (2009).

\section{Measures}




\section{Dependent Variable: Social Welfare Policy Attitudes}

The dependent variable for this study examines the extent to which respondents oppose spending cuts to public assistance or welfare such that 1 is associated with opposition to and to and zero is associated with support for such cuts.

\section{Independent Variables: Issue-based Sermons}

The sermon variable assessed if respondents had heard a sermon, lecture, or discussion at their place of worship that dealt with jobs, the economy or the poor such that 0 denotes that they do not attend worship services ${ }^{1}, 1$ denotes they attend, but they had not, in the past year, heard sermons on jobs, the economy, or the poor, and 2 denotes that worshipgoers had heard such sermons.

\section{Control Variables: Social-Demographic Characteristics}

Because of the importance of social-demographic characteristics to social welfare attitudes, our multivariate analyses also account for age, gender, education, region, family income, employment status, and religious faith. We also account for political partisanship and ideology. We include these two indicators because ample empirical evidence reveals that Democrats and liberals have a higher likelihood of endorsing government spending directed toward the poor than Republicans and conservatives (Green, 2004; 2008). ${ }^{\text {i2 }}$

\section{Results}

Overall, our analyses suggest that while African Americans are more likely than Whites to hear sermons at their houses of worship about poverty-related issues, hearing these sermons maintains a stronger association with White opposition to cuts to social welfare spending than it does for both Blacks and Hispanics. These analyses also reveal that although Whites that do not hear poverty-related sermons at their places of worship are considerably

\footnotetext{
${ }^{1}$ These individuals attend worship services less than once a month. As a consequence, they were not asked about sermons.

${ }^{2}$ Missing values for age, income, and political ideology are replaced by the Imputation by Chained Equations multiple imputation method on STATA 13. The imputed variables do not substantively or significantly change the outcomes of these analyses.
}

This article is protected by copyright. All rights reserved. 
less likely than Blacks and Hispanics to oppose cuts to social welfare spending, Whites that hear such sermons maintain social welfare attitudes that are quite similar to that of Blacks and Hispanics. We discuss these findings in greater detail below.

\section{Race, Religion, and Government Support for the Economically Disadvantaged}

The analysis reported in Table 1 indicates that a majority of each racial/ethnic group reports hearing sermons about economic-related issues and oppose cuts to social welfare spending. Consequently, African American worship-goers are more likely than are their White counter-parts to hear sermons in their places of worship about jobs, the economy, and the poor and to oppose cuts to social welfare spending. We also find that while Hispanics are no more or less likely than Whites to hear sermons about economic-related issues, they, like African Americans, are more likely than Whites to oppose cuts to social welfare spending.

Similar to Table 1, and as expected, the relative risk ratios reported in the multinomial logit regression analyses of Table 2 indicate that African American worship-goers are less likely than are their Non-Hispanic White counterparts to attend religious services where they do not hear sermons on jobs, the economy, and the poor. African Americans are also less likely than Non-Hispanic Whites to refrain from attending worship services altogether than they are to hear sermons on such issues. In contrast, Hispanics are no more or less likely than Whites to hear sermons on these issues at their place of worship, or to not attend at all. We now move on to examining racial/ethnic differences in the association between hearing such sermons and opposition to cuts in social welfare spending.

Religion and Social Welfare Policy Attitudes among Whites, Blacks, and Hispanics

As expected, the odds ratios reported in the logit analyses of Table 3 indicates that while exposure to sermons about jobs, the economy, and the poor associates with more progressive social welfare attitudes among Whites, we find no such relationship among African Americans and Hispanics. To the point, White worship-goers that do not hear 
sermons about jobs, economy, and the poor are less likely than White worship-goers that hear such sermons to oppose cuts to social-welfare spending. Among African Americans and Hispanics, however, exposure to such sermons is unrelated to their social welfare policy attitudes. In addition, among all three groups, religious faith is unrelated to social welfare policy attitudes. In short, we find that while White worship-goers that hear sermons on political issues are more likely than other White worship-goers to oppose cuts to social welfare spending, such is not the case for African Americans and Hispanics. Treatment Effects; Religion and Social Welfare Policy Attitudes among Whites

In addition to the standard logit regression analyses, we employed treatment effect analyses via STATA 13 to estimate the causal effect of our sermon treatments on our outcome, social welfare policy attitudes among Non-Hispanic Whites: the one group in which we observed a significant relationship ${ }^{3}$. We do this to explore the likely outcome of every White worship-goer being exposed to a sermon on poverty-related issues within their place of worship. This allows us to address the empirical contention that exposure to sermons on jobs, the economy, and the poor may involve some level of bias with some individuals selfselecting places of worship that match their interests in this and related issues. By having a simulated treatment of the same level of potential exposure to worship discourse on jobs, the economy, and the poor, we attempt to address this problem. That said, the treatment effect based upon the White analyses of Table 3, listed within Table A of the Appendix, provides a baseline estimate of the proportion of White Americans that would oppose cuts to social welfare spending, which was $73.9 \%$, had the entire population of worship-going Whites been exposed to a poyerty-related sermon in their worship setting (e.g. (Base) Attend Worship / Sermon). It also provides us with the average treatment effect, which estimates opposition to social welfare spending cuts assuming that worship-going Whites were not exposed to such

\footnotetext{
${ }^{3}$ See, StataCorp. 2013. Stata treatment-effects Reference manual: potential outcomes/counterfactual outcomes: Release 13. College Station, TX. Stata Press.
}

This article is protected by copyright. All rights reserved. 
sermons in their place of worship (e.g. Attend Worship / No Sermon). This estimate indicates that only $54.8 \%$ of White worship-goers would have opposed such spending cuts had this population not heard about the afore-mentioned issues at their place of worship. This $19.1 \%$ drop in support represents a statistically significant difference. In sum, our treatment affect analyses complement our logit regression analyses by providing a greater degree certainty that exposure to poverty-related sermons within worship settings associates with and likely informs anti-poverty attitudes among Non-Hispanic White Americans. Race, Religion, and Social Welfare Policy Attitudes

The analyses presented thus far suggest that while African Americans are more likely than Whites to hear sermons on poverty-related issues (see Tables $1 \& 2$ ), hearing such sermons associates with opposition to spending cuts to social welfare programs among NonHispanic Whites only. Among African Americans and Hispanics, we find no such relationship (see Table 3). We now examine the extent to which hearing these types of sermons maintains a statistically stronger relationship with such attitudes among Whites than among African and Hispanic Americans.

The analyses presented in Table 4 and illustrated in Figure 1 provide some evidence that this may be the case. More specifically, the Black*Sermon interaction term is less than one and statistically significant. The main effect of hearing sermons on jobs, the economy, and the poor represents the likelihood that hearing such sermons is associated with opposition to cuts to social welfare spending when African American is zero (e.g. the respondent is White). This odds ratio is greater than one and significantly different from zero, indicating that hearing such sermons associates with opposing such spending cuts among Whites. Conversely, Blacks that hear such sermons are no more or less likely than other Blacks to oppose these cuts. In short, hearing sermons on jobs, the economy, and the poor has a significantly stronger relationship with opposing cuts to social welfare spending among 
Whites than it does among African Americans. Hearing such sermons also has a significantly stronger relationship with Whites opposing cuts to welfare spending than it has for Hispanic Americans ${ }^{\mathrm{ii} 4}$

The interaction terms and probability estimates of Figure 1 also indicate that Black and Hispanic worship-goers that are not exposed to sermons about poverty-related issues are more likely than their White counter-parts to oppose cuts to social welfare programs.

However, we find no racial/ethnic difference in opposition to cuts to social welfare spending among worship goers that $d o$ hear sermons on poverty-related issues. That is, while White worship-goers that hear no sermons on economic issues maintain a considerably lower probability than Blacks and Hispanics to oppose cuts to social welfare spending, the social welfare attitudes of Whites that hear such sermons very closely resemble the social welfare policy attitudes of Blacks and Hispanics.

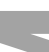

\section{Discussion}

That African Americans are more likely than Whites to be poor and live within communities of concentrated poverty, to experience unemployment and be outside of the labor force, to fare worse during economic recessions may help explain why African Americans are more comfortable with their clergy preaching on poverty-related concerns. Along these lines, local Black religious congregations are often the only institution to which African Americans are connected that enables them to air their concerns and provide leadership opportunities necessary for building civic skills to engage in political action (Brown \& Brown, 2003; Lincoln \& Mamiya, 1990; McDaniel, 2008; Morris, 1986). These contrasting racial/ethnic experiences and outlooks on religion likely provide some

\footnotetext{
${ }^{4}$ It is worth noting that we replicated these analyses on five other national data sets with measures on sermon content and social-welfare policy attitudes and found roughly the same pattern of relationships. The data sources are the following; 1990 American Citizen Participation Study, 1996 Religion and Politics Study, 2000 Religion and Politics Study, 2006 Faith Matters Study, and the 2010 Religion and Public Life Study. These analyses are available upon request.
}

This article is protected by copyright. All rights reserved. 
explanation for why African Americans are more likely than Whites to attend congregations where their clergy preach on poverty-related concerns.

That said, while Hispanic Americans tend to share economic experiences similar to African Americans than to Whites, they are no more or less likely than Whites to hear sermons about poverty-related issues. The immigrant status and identity of Hispanic Americans may help explain why Hispanics - three-quarters of whom are first or second generation immigrants - are not statistically different from Whites in their likelihood of exposure to sermons on poverty-related issues. That is, experiencing and/or identifying with immigrants may contribute to Hispanics comparing the economic opportunities available within the communities from which they, family members, and friends immigrated with economic opportunities within the U.S. Indeed, at $3 / 4$ in strong agreement, Hispanic Americans are far more likely than Blacks, Whites, Asians, and Afro-Caribbean Americans to believe that the U.S. is a land of opportunity in which one only has to work hard to get ahead (Jackson et. al, 2009). Similarly, Hispanics are considerably less likely than Blacks to believe that their group experiences discrimination or that their group has generally been treated unfairly (Jackson et. al, 2009). As such, the relative hope for greater opportunities for economic stability and mobility may lead Hispanics to believe relatively optimistic about their experiences and feel that hardships are temporal setbacks that can be ameliorated via hard work. This outlook may contribute to Hispanic Americans, as a group, being less likely to define their economic experiences as hardships and/or to publicly define their experiences in worship settings as such. This frame of their economic experiences may contribute to their clergy also refraining from discussing economic conditions as hardships. At this point, however, we are only able to speculate, as further study is needed that examines contributing factors to receptivity and exposure to sermons on poverty-related issues among Hispanics. 
To be clear, while Blacks are more likely than Whites to hear sermons about poverty, it is not a given that all sermons about poverty convey the message that the human dignity and respect that Tillich and King speak of are only possible if the national government increases its commitment to the poor (King, 1967; Tillich, 1973). As stated earlier, it is quite plausible that many sermons about poverty do not go beyond the experiential in discussing how to cope with trying experiences, offer spiritual and social support to those in need, and to recognize blessings despite hardships. The extent to which exposure to sermons associate with social welfare policy attitudes provides some indication of the content, interpretation, and applicability of such messages to congregants' social welfare attitudes. That said, the current study suggests that hearing sermons about poverty-related concerns plays a considerably more important role in shaping and/or reinforcing progressive social welfare attitudes among Whites than among Blacks and Hispanics.

The contrasting racial experiences of marginalization and dominance among Whites, Blacks, and Hispanics may help explain these findings. Relative to Blacks and Hispanics, progressive worship settings are one of relatively few social spaces that reinforce and significantly strengthen political attitudes of White liberals. Consequently, Whites that hold a liberal theological world view are seemingly comfortable in religious settings that attract and retain progressive minded Americans. In these settings, liberal clergy likely utilize their time in the pulpit to move congregants to struggle with the idea that their historical and future spiritual and political destinies as believers and practitioners of the gospel are tied to that of the poor and social-politically marginalized (Slessarev-Jamir, 2011). In doing so, many clergy go beyond contemplation to encouraging and providing opportunities for congregants to politically struggle with marginalized groups to make society more just and equitable (Slessarev-Jamir, 2011; Warren, 2001; Wood, 2002). Indeed, exposure to sermons about poverty maintains a clear association with progressive White social-welfare attitudes and 
contributes to White views on the government's obligation to the poor resembling that of Blacks and Hispanics.

Conversely, the disproportionate lived experience with poverty, as well as personal connections via the experiences of friends and family, among Blacks and Hispanics likely contributes to their religious institutions complimenting, rather than shaping and/or reinforcing, their relatively strong support for anti-poverty policy. For far more Blacks and Hispanics than Whites, hearing messages about poverty and inequality in worship spaces likely constitutes just one of many opportunities they have to talk and think about and experience poverty. From this perspective, it is understandable why we rarely observe a relationship between sermon exposure and anti-poverty policy attitudes among Blacks and Hispanics, In sum, the present study indicates that while African Americans are more likely than Whites to hear sermons about poverty and other political issues, these religious messages maintain a stronger association with the progressive social welfare attitudes of Whites than with Blacks and Hispanics.

We recognize that still much is to be said and understood about how sermons about poverty-related issues differentially inform social-welfare attitudes along racial/ethnic lines. Future research that allows for longitudinal design and/or in-depth interviews would allow us to speak more definitively on the causal direction of our findings. Following the guide of Djupe and Gilbert's (2008) examination of the association between clergy's position on gay rights and congregant position on this issue, examinations of the actual content of sermons would also allow us to more clearly examine how clergy's position on poverty-related policy issues inform/reinforce the policy attitudes of White, Black, and Hispanic congregants. Despite these limitations, the current empirical investigation is the only study of which we are aware that examines the intersection between race, religion, and anti-poverty attitudes. 
As such, this study provides a basis to pursue future studies that move us closer to understanding how religion informs commitments to economic justice.

\section{Conclusion}

So what do our findings tell us about the possibility of religious Americans utilizing the public sphere to voice their support for government programs aimed at alleviating economic suffering? As the work on faith-based community organizing firms suggest, our findings imply that there is great potential for Whites, Blacks, and Hispanics that are committed to social justice to jointly work through their religious congregations and engage in social movement activities to increase economic opportunities for Americans on the economic margins (Warren, 2001; Wood, 2002). That said, religious activists committed to social justice and their allies face serious challenges in actually influencing public policy. The 2010 and 2014 Supreme Court Rulings concerning the Federal Election Commission (FEC) make such challenges abundantly clear. In the 2010 Citizen United vs FEC case, the Supreme Court ruled that corporations, unions, and non-profit organizations have the constitutional right to donate unlimited amounts of money to Super PACs. Four years later in McClutchen vs. FEC, the Supreme Court ruled that individuals have the constitutional right to donate unlimited amounts of money to political candidates and parties. These two rulings put progressive organizations, religious and non-religious alike, at a serious disadvantage when trying to influence public opinion and policy.

Even before these rulings, American public policy has almost been completely controlled by the interests and desires of the super wealthy. A recent study (Gilens 2012) indicates that between 1981 and 2002, American domestic and foreign policy outcomes were unrelated to the public opinion of middle class, working class, and poor Americans. Rather, policy output was strongly connected to the interests of corporate leaders and the super wealthy. This was the case, regardless of party control of Congress and/or the white house. 
This reality may on the one hand point to the futility of Americans connected to progressive religious organizations and their allies in presenting a counter-narrative to social inequality and encouraging their congregants to take political action. On the other hand, the decline of labor unions as a major progressive institution may suggest the necessity for religious institutions to continue to challenge the seemingly ubiquitous ideal that social inequality is acceptable and unworthy of any public discussion (DeSilver, 2015). This point is well exemplified in the June 14, 2007 letter from the Most Rev. Nicholas DiMarizo, Chair of the Domestic Policy Committee, United States Conference of Catholic Bishops, and Rev. Larry Snyder of Catholic Charities to Rep. Joe Baca (CA-D), urging him to support "necessary and improved funding for the Food Stamp Program and other nutrient programs to ensure food assistance to those facing hunger or malnutrition”. Influencing public opinion and congress on the need for well-funded anti-poverty initiatives is indeed an uphill political battle. A January 2015 report from the Congressional Budget Office reveals that the value of federal funding, for the main grant-Temporary Assistance for Needy Families-to assist the poor, adjusting for inflation, declined by about 25 percent from 1998 to 2013(CBO, 2015). While the efforts of the likes of Revs. DiMarzio and Snyder are seemingly futile, a broader look at history would suggest that one goal of social movements is to increase awareness of social problems so that a sympathetic and informed public are willing to engage in policy change activities when political opportunities present themselves (Nepstad, 2004).

Although Whites that attend congregations that speak about poverty are more likely than other worship-going Whites to support progressive causes, these religious spaces have to walk a figurative tightrope to remain relevant and alive. History suggests that if there is too much discussion about poverty and social inequality within the religious spaces that Whites predominate, religious leaders may risk losing current and potentially future members that disagree with their theological and political worldview. Indeed, only $10 \%$ of predominantly 
White congregations have a heavy social justice mission orientation and are vastly underrepresented among faith-based community organizing firms politically engaged in improving social-economic opportunities for disadvantaged groups (Brown, 2009). This reality may speak to the threshold for social justice among many White American worship-goers. It also speaks to the hurdles confronting leaders of religious congregations that attract large numbers of Whites who, on the one hand, desire to fellowship with the poor, but have members that do not wish to hear too many sermons about economic inequality and/or the government obligation to the poor. Lastly, the challenge for many progressive congregations in an age of expanding social inequality is to rekindle the anti-poverty flame lit by President Johnson and Martin Luther King during the 1960s to move religious Americans to work toward the eradication of structural barriers that limit the life chances of the nation's poor.

\section{References}

Bellah, Robert N. 1975. The Broken Covenant: American Civil Religion in Time of Trial. New York: The Seabury Press Inc.

Bobo, Lawrence. "Group conflict, prejudice, and the paradox of contemporary racial attitudes." Eliminating racism. New York, NY: Springer US, 1988. 85-114.

Brown, R. Khari, and Ronald E. Brown. 2003. "Faith and works: Church-based social capital resources and African American political activism." Social Forces 82.2: 617-641.

Brown, R. Khari. 2009. "Racial/ethnic differences in the political behavior of American religious congregations." Sociological Spectrum 29.2: 227-248.

Brown, R. Khari and Ronald E. Brown. 2014. "Race, Religion, and Political Leanings." Under Review.

Chen, Daniel L. and Jo Thori Lind. 2007. "Religion, Welfare, Politics, and ChurchState Separation.” Journal of Ecumenical Studies. 42 (1): 42-52. 
Clanton, J. Caleb. 2008. Religion and Democratic Citizenship: Inquiry and

Conviction in the American Public Square. Lanham, MD: Lexington Books.

Congressional Budget Office: U.S. Congress. 2015. Temporary Assistance for Needy Families: Spending and Policy Options, (January). http://www.cbo.gov/publication/49887, accessed May 16, 2015.

Desilver, Drew. 2015. Job categories where union membership has fallen off most. Pew Research Center, April 27. Accessed on April 28, 2015 from, http://www.pewresearch.org/fact-tank/2015/04/27/union-membership/

Rev. Nicholas DiMarizo, Chairman, Domestic Policy Committee, United States Conference of Catholic Bishops and Rev. Larry Snyder, President of Catholic Charities, U.S.A. to Representative Joe Baca, Chairman of Sub Committee on Department Operations, Oversight, Nutrition and Forestry, House Committee on Agriculture, June 14, 2007, Department of Social Development and World Peace, http://usccb.org/issues-andaction/human-life-and-dignity/agriculture-nutrition-rural-issues/archives.cfmm, accessed May 16, 2015.

Djupe, Paul A., and Christopher P. Gilbert. 2008. The political influence of churches. New York, NY: Cambridge University Press.

Durkheim, Emile. 1995. The Elementary Forms of Religious Life. New York, NY: Free Press.

Gallup. 2014. “Confidence in Institutions." The Gallup Poll. Accessed on June 30, 2014 from, http://www.gallup.com/poll/1597/confidence-institutions.aspx

Geertz, Clifford. 1977. The Interpretation of Cultures. New York, NY: Basic Books Classics.

Gilens, Martin. 1999. Why Americans Hate Welfare: Race, Media, and the Politics of Anti-Poverty Policy. Chicago, IL: University of Chicago Press. 
Gilens, Martin. 2012. Affluence and Influence: Economic Inequality and Political Power in America. Princeton, NJ: Princeton University Press.

Green, John C. 2004. The American Religious Landscape and Political Attitudes: A Baseline for 2004. The University of Akron's Bliss Institute of Applied Politics-Pew Forum on Religion and Public Life. Accessed on December 14, 2013 from; https://www.uakron.edu/pages/bliss/docs/Religious_Landscape_2004.pdf.

Green, John C. 2008. The Fifth National Survey of Religion and Politics: A Baseline for the 2008 Presidential Election. The University of Akron's Bliss Institute of Applied Politics. Accessed on December 14, 2013 from; http://www.npr.org/documents/2008/oct/bliss_report.pdf.

Groves, Robert M. 2006. Nonresponse rates and nonresponse bias in household surveys.

The Public Opinion Quarterly 70 (5): 646-675.

Hall, Charles F. 1997. "The Christian Left: Who are they and how are they different from the Christian Right?" Review of Religious Research. 39 (1): 27-45.

Harris, Fredrick C. 1999. Something within: Religion in African-American political activism. New York: Oxford University Press.

Independent Sector. 2002. "Faith \& Philanthropy: The Connection Between Charitable Behavior and Giving to Religion."

Jackson, James S., Vincent L. Hutchings, Ronald Brown, and Cara Wong. 2009. National Politics Study, 2004 [Computer file]. ICPSR24483-v1. Ann Arbor, MI: Interuniversity Consortium for Political and Social Research [distributor], 2009-03-23. doi: 10.3886/ ICPSR 24483.

Jones, Charles B. 2007. Introduction to the Study of Religion: Course Guidebook. Chantilly, Virginia: The Teaching Company. 
Kinder, Donald R. and Lynn Sanders. 1996. Divided by color: Racial politics and democratic ideals. Chicago, IL: University of Chicago Press.

King Jr., Martin Luther. 1967. Where Do We Go from Here: Chaos or Community? Boston, MA: Beacon Press.

Kohut, Andrew, Kimberly Parker, Margaret Petrella, and Claudia Deane. 1996. The Diminishing Divide ...American Churches, American Politics. Pew Research Center for The People \& The Press. June 25. Accessed on July 2, 2014 from http://www.peoplepress.org/files/legacy-pdf/126.pdf

Kohut, Andrew, Carroll Doherty, Michael Dimock, and Scott Keeter. 2012. "Trends in American Values: 1987-2012: Partisan Polarization Surges in Bush, Obama Years." Pew Research Center. Accessed on June 30, 2014 from, http://www.people-press.org/files/legacy-pdf/06-04-12\%20Values\%20Release.pdf

Lincoln, C. Eric and Lawrence H. Mamiya. The Black Church in the African American Experience. Durham, NC: Duke University Press.

McDaniel, Eric L. 2008. Politics in the Pews: The Political Mobilization of Black Churches. Ann Arbor, MI: The University of Michigan Press.

Morris, Aldon D. 1984. Origins of the Civil Rights Movements. New York, NY: The Free Press.

Mendelberg, Tali, and John Oleske. 2000. "Race and public deliberation." Political Communication, 17 (2): 169-191.

Morone, James A. Hellfire nation: The politics of sin in American history. 2003.

New Haven, CN: Yale University Press.

Neiheisel, Jacob R., Paul A. Djupe, and Anand E. Sokhey. 2009. "Veni, vidi, disseri: Churches and the promise of democratic deliberation." American Politics Research, 37 (4): 614-643. 
Nepstad, Sharon Erickson. 2004. Convictions of the Soul: Religion, Culture, and Agency in the Central America Solidarity Movement. New York: Oxford University Press.

Neuhaus, Richard John. 1970. “The War, the Churches, and Civil Religion.” Annals of the American Academy of Political and Social Science, 387 (Jan.): 128-140.

Pew Research Center. 2010. "Religion and the Issues: Few Say Religion Shapes Immigration, Environment Views: Results from the 2010 Annual Religion and Public Life Survey." Pew Research Center for the People \& the Press/ Pew Forum on Religion \& Public Life. Sept. 17. Accessed on June 30, 2014 from, http://www.pewforum.org/files/2010/09/immigration-environment-views-fullreport.pdf Pitkin, Hanna Fenichel. 1967. The Concept of Representation. Berkeley and Los Angeles, CA.: University of California Press.

Poor People's Campaign. 2014. Accessed on July 3, 2014 from, http://mlkkpp01.stanford.edu/index.php/encyclopedia/encyclopedia/enc_poor_peoples_campaign/ PRRI/RNS. 2011. "Survey | Plurality of Americans believe capitalism at odds with Christian values.” Public Religion Research Institute/Religion News Service, April 20, 2014. Accessed on December 26, 2013 from, http://www.thearda.com/Archive/Files/Descriptions/PRRIRNA.asp

Putnam, Robert D., and David E. Campbell. 2012. American grace: How religion an divides and unites us. New York, NY: Simon and Schuster.

Putnam, Robert D. Thomas Sanders, and David E. Campell, 2011; Faith Matters, 2011. Accessed on May 9, 2015 from, http://www.thearda.com/Archive/Files/Descriptions/FTHMAT11.asp Pyle, Ralph E. 1993. "Faith and Commitment to the Poor: Theological Orientation and Support for Government Assistance Measures.” Sociology of Religion. 54 (4): 385-401. 
Quinley, Harold E. 1974. The prophetic clergy: Social activism among Protestant ministers. Hoboken, NJ: John Wiley \& Sons.

Rauschenbusch, W. (1917). A Theology for the Social Gospel. Louisville, KY:

Westminster John Knox Press.

Roozen, David A., McKinney, William, \& Carroll, Jackson W. 1984. Varieties of religious presence: Mission in public life. Pilgrim Press.

SCBS, 2000. 2014. Original analyses conducted on Social Capital Community Benchmark Survey, 2000 (SCBS, 2000), by the author.

Slessarev-Jamir, Helene. 2011. Prophetic Activism: Progressive Religious Justice Movements in Contemporary America. New York, NY: New York University Press.

Steensland, Brian. 2002. 'The Hydra and the Swords: Social Welfare and Mainline Advocacy, 1964-2000', in The Quiet Hand of God: Faith-Based Activism and the Public Role of Mainline Protestantism, ed. Robert Wuthnow and John H. Evans. Berkeley, CA: University of California Press.

Steensland, Brian, Jerry Z. Park, Mark D. Regnerus, Lynn D. Robinson, W. Bradford Wilcox, and Robert D. Woodberry. 2000. "The measure of American religion: Toward improving the state of the art." Social Forces 79 (1): 291-318.

Tarman, Christopher and David O. Sears. 2005. "The Conceptualization and Measurement of Symbolic Racism.” The Journal of Politics, 67 (3): 731-761.

Tillich, Paul. 1973. Systematic Theology, vol. 1. Chicago, IL: University of Chicago Press.

Verter, Bradford. 2002. "Furthering the Freedom Struggle: Racial Justice Activism in the Mainline Churches since the Civil Rights Era." , in The Quiet Hand of God: Faith-Based Activism and the Public Role of Mainline Protestantism, ed. Robert Wuthnow and John H. Evans. Berkeley, CA: University of California Press. 
Wald, Kenneth D. and Allison Calhoun-Brown. 2010. Religion and Politics in the United States: Sixth Edition. New York, NY: Rowman \& Littlefield Publishers.

Warren, Mark. 2001. Dry Bones Rattling: Community Building to Revitalize

American

Democracy. Princeton, NJ: Princeton University Press.

Warren, Mark C. and Richard L. Wood. 2002 "A Different Face of Faith-based Politics: Social Capital and Community Organizing in the Public Arena." International Journal of Sociology and Social Policy 22 (No. 9/10): 6-54.

Weber, Max. 2013. The Protestant Ethic and the Spirit of Capitalism. London, UK: Routledge Press.

West, Guida. 1981. The national welfare rights movement: The social protest of poor women. Westport, CT: Praeger Publishers.

Wilson, J. Matthew. 1999. “Blessed are the Poor:” American Protestantism and Attitudes toward Poverty and Welfare." Southeastern Political Review. 27 (3): 421-437.

Wood, Richard L. 2002. Faith in Action: Religion, Race, and Democratic Organizing in America. Chicago, IL: University Of Chicago Press.

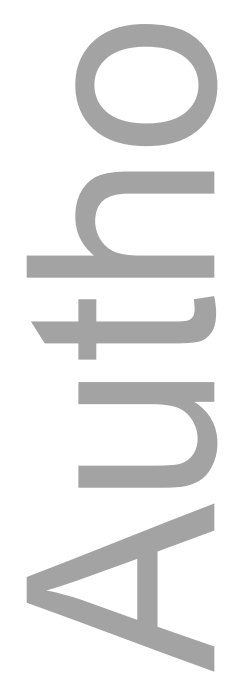


Table 1: Opposition to Cuts to Welfare Spending and Exposure to Sermons on Jobs, Economy, and the Poor by Race/Ethnicity

\begin{tabular}{|l|l|l|}
\hline & $\begin{array}{l}\text { \% Oppose Cuts to Welfare } \\
\text { Spending }\end{array}$ & $\begin{array}{l}\text { \% Heard Sermon on } \\
\text { Jobs/Economy/ Poor }\end{array}$ \\
\hline White & 65.13 & 54.61 \\
\hline $\mathrm{N}=$ & 519 & 412 \\
\hline $\mathrm{Black}$ & $72.34 * *$ & $63.16^{*}$ \\
\hline $\mathrm{N}=$ & 329 & 304 \\
\hline $\mathrm{Hispanic}$ & $77.03^{* *}$ & 53.05 \\
\hline $\mathrm{N}=$ & 444 & 394 \\
\hline
\end{tabular}

$*<.05, * *<.01$

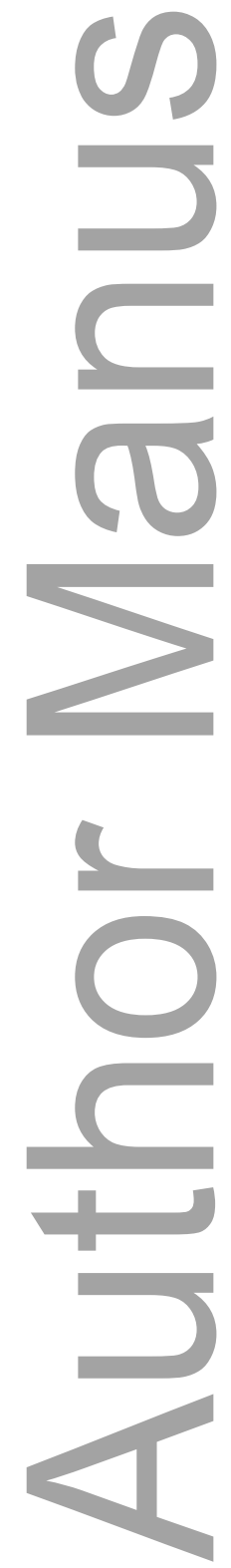

\footnotetext{
${ }^{5}$ Among individuals that attend worship service at least once a month.
}

This article is protected by copyright. All rights reserved. 
Table 2: Relationship between Race/Ethnicity and Exposure to Sermons on Jobs, Economy, and the Poor: Mutlinomial Logit Regression Analyses: Relative Risk Ratios ${ }^{6}$

\begin{tabular}{|l|l|l|}
\hline & $\begin{array}{l}\text { Attending Worship Service } \\
\text { with NO Poverty Sermon VS } \\
\text { Attending Worship Service } \\
\text { WITH Poverty Sermon }\end{array}$ & $\begin{array}{l}\text { NOT Attending Worship } \\
\text { Services VS Attending } \\
\text { Worship Services WITH } \\
\text { Poverty Sermon }\end{array}$ \\
\hline Black $^{7}$ & $.583(.401-.851)^{* *}$ & $.362(.197-.666)^{* *}$ \\
\hline Hispanic & $.952(.651-1.392)$ & $.639(.355-1.149)$ \\
\hline $\mathrm{N}=1,292 ;$ Log likelihood $=-1120.972$ & \\
$*<.05, * *<.01$ &
\end{tabular}

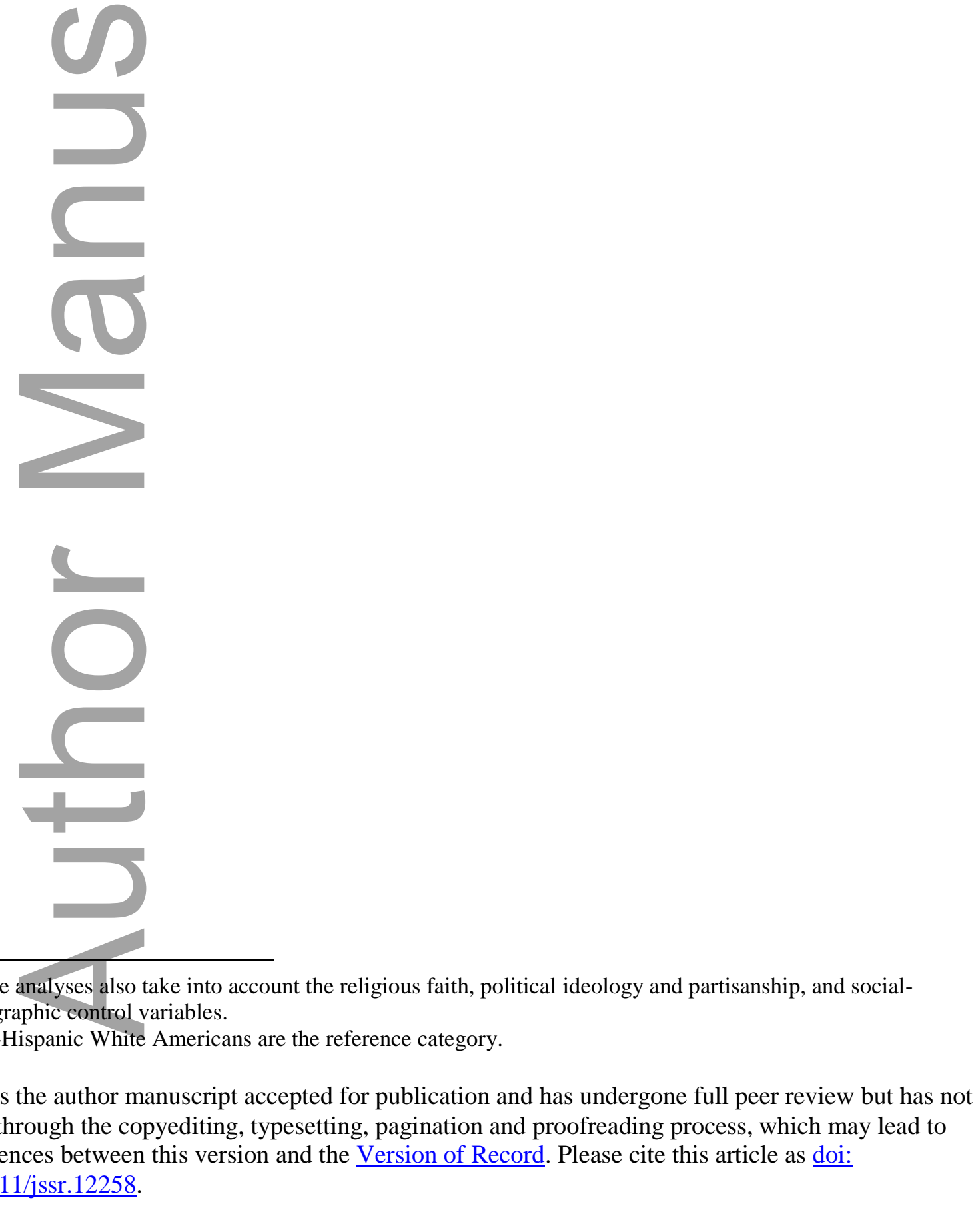

\footnotetext{
${ }^{6}$ These analyses also take into account the religious faith, political ideology and partisanship, and socialdemographic control variables.

${ }^{7}$ Non-Hispanic White Americans are the reference category.
}

This is the author manuscript accepted for publication and has undergone full peer review but has not been through the copyediting, typesetting, pagination and proofreading process, which may lead to differences between this version and the Version of Record. Please cite this article as doi: $\underline{10.1111 / \text { jssr. } 12258}$

This article is protected by copyright. All rights reserved. 
Table 3: Relationship between Exposure to Sermons on Jobs, Economy, and the Poor and Opposition to Cuts to Social Welfare Spending by Race/Ethnicity: Logit Regression Analyses: Odds Ratios ${ }^{8}$

\begin{tabular}{|c|c|c|c|}
\hline & Whites & Blacks & Hispanics \\
\hline \multicolumn{4}{|l|}{ Sermons $^{9}$} \\
\hline $\begin{array}{l}\text { Attend Worship / No } \\
\text { Sermon }\end{array}$ & $\begin{array}{l}0.467 * *(0.297- \\
0.734)\end{array}$ & $1.015(0.558-1.848)$ & $1.358(0.813-2.267)$ \\
\hline $\begin{array}{l}\text { Does Not Attend } \\
\text { Worship Service }\end{array}$ & $0.696(0.361-1.341)$ & $0.476(0.182-1.241)$ & $1.698(0.715-4.035)$ \\
\hline \multicolumn{4}{|l|}{ Religious Faith $^{\text {I0 }}$} \\
\hline Mainline Protestant & $1.029(0.583-1.816)$ & --- & --- \\
\hline Catholic & $1.208(0.683-2.136)$ & --- & $1.238(.743-2.061)$ \\
\hline Other Faith & $1.160(0.590-2.280)$ & --- & --- \\
\hline $\begin{array}{l}\text { Religious } \\
\text { Unaffiliated }\end{array}$ & $0.958(0.445-2.062)$ & --- & --- \\
\hline Black Protestant & --- & $0.942(0.538-1.650)$ & --- \\
\hline $\mathrm{N}=$ & 519 & 329 & 444 \\
\hline Log-likelihood & -298.06154 & -173.7946 & -211.92063 \\
\hline
\end{tabular}

$*<.05, * *<.01 ; 95 \%$; confidence intervals in parentheses

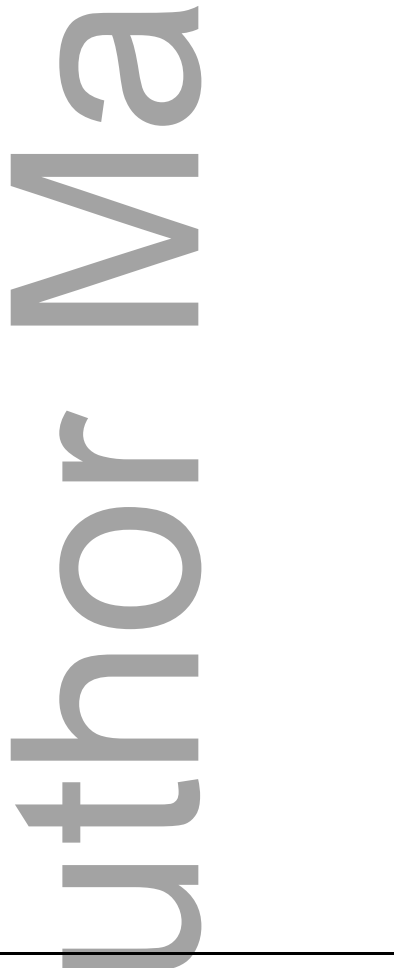

\footnotetext{
${ }^{8}$ These analyses also take into account the social-demographic control variables as well as political partisanship and ideology

${ }^{9}$ In Tables 3 and 4, Attending Worship Services and Hearing Sermons on Jobs, the Economy, and the Poor is the reference category for the Sermon variable.

${ }^{10}$ Evangelical Protestant is the reference category for the Religious Faith Variable.
}

This is the author manuscript accepted for publication and has undergone full peer review but has not been through the copyediting, typesetting, pagination and proofreading process, which may lead to differences between this version and the Version of Record. Please cite this article as doi: $\underline{10.1111 / \text { jssr. } 12258 .}$.

This article is protected by copyright. All rights reserved. 
Table 4: Moderating Impact of Race/Ethnicity on the Relationship between Hearing Sermons on Jobs, the Economy, and the Poor and Opposition to Cuts to Social Welfare Spending among Worship-Goers: Logit Regression Analyses: Odds Ratios ${ }^{11}$

\begin{tabular}{|l|l|}
\hline Interactions $^{12}$ & \\
\hline Blacks * Poverty Sermon & $0.385^{* *}(0.190-0.782)$ \\
\hline Hispanics* Poverty Sermon & $0.319^{* *}(0.163-0.623)$ \\
\hline Race/Ethnicity & \\
\hline Blacks & $2.291(1.263-4.156)^{* *}$ \\
\hline Hispanics & $3.444(1.938-6.121)^{* *}$ \\
\hline & \\
\hline Poverty Sermon & $2.132(1.383-3.289)^{* *}$ \\
\hline $\mathrm{N}=$ & 1,110 \\
\hline Log Likelihood & -603.780 \\
\hline
\end{tabular}

$*<.05, * *<.01 ; 95 \%$; confidence intervals in parentheses

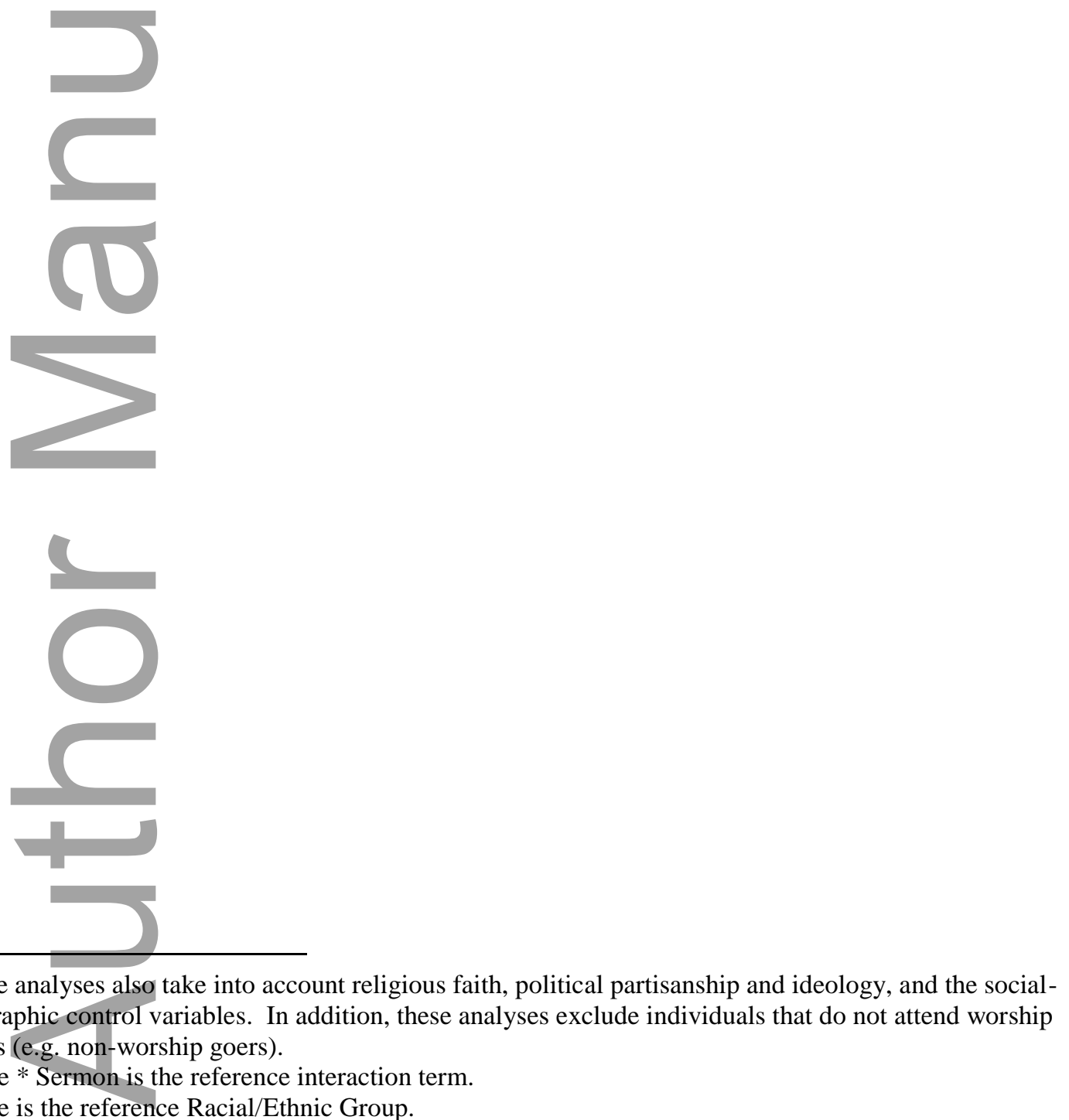

${ }^{11}$ These analyses also take into account religious faith, political partisanship and ideology, and the socialdemographic control variables. In addition, these analyses exclude individuals that do not attend worship services (e.g. non-worship goers).

${ }^{12}$ White * Sermon is the reference interaction term.

${ }^{13}$ White is the reference Racial/Ethnic Group.

This is the author manuscript accepted for publication and has undergone full peer review but has not been through the copyediting, typesetting, pagination and proofreading process, which may lead to differences between this version and the Version of Record. Please cite this article as doi: $\underline{10.1111 / \text { jssr. } 12258 .}$.

This article is protected by copyright. All rights reserved. 


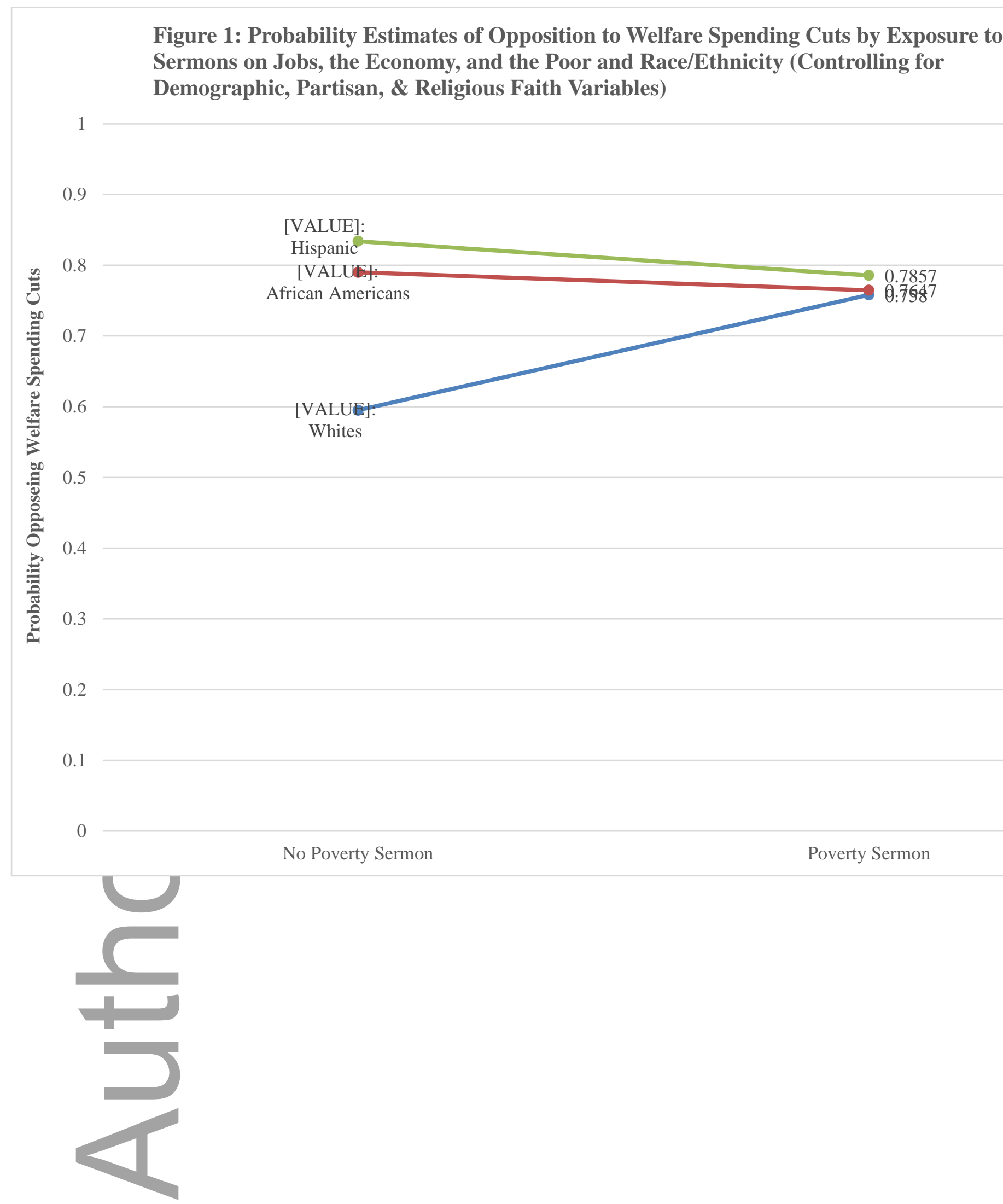




\section{Appendix}

Table A: Treatment Effects of the Relationship between Exposure to Sermons on Jobs, the Economy, and the Poor and Opposition to Cuts to Social Welfare Spending among Non-Hispanic Whites ${ }^{14}$

\begin{tabular}{|l|l|}
\hline \multicolumn{2}{|l|}{} \\
\hline Attend Worship / No Sermon & Average Treatment Effect \\
\hline & $-.191^{* *}(-.294--.088)$ \\
\hline (Base) Attend Worship / Sermon & Population Mean \\
\hline $\mathrm{N}=$ & $.739^{* *}(.680-.798)$ \\
\hline
\end{tabular}

$*<.05 ; * *<.01 ;$ Confidence Intervals in Parentheses

' See Pitkins, 1967

ii The probability estimates listed in Figure 1 are derived from logit regression analyses reported in Table 3 . As such, the estimates reported in Figure 1 reflect the probability of opposing cuts to welfare spending among White worship goers that do not hear sermons about jobs, the economy, and the poor and those that hear such sermons. As in Table 3, these estimates also control for the remaining independent variables in those logit regression analyses. That being said, the estimates for Figure 1 are based upon the following formula;

$\operatorname{Pr}(\mathrm{y}=1 \mid \overline{\mathrm{X}}, \max \mathrm{xk})-\operatorname{Pr}(\mathrm{y}=1 \mid \overline{\mathrm{X}}, \min \mathrm{xk})$, in which Y represents anti-poverty attitudes and $\mathrm{X}$ represents exposure to political issue-based sermons among worship-goers.
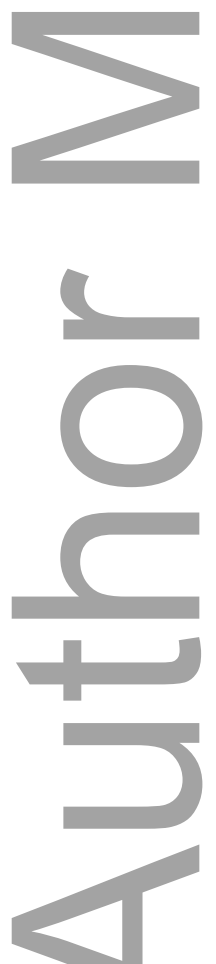

${ }^{14}$ These analyses implement the same controls listed within the Logit Regression Analyses of Table 3.

This is the author manuscript accepted for publication and has undergone full peer review but has not been through the copyediting, typesetting, pagination and proofreading process, which may lead to differences between this version and the Version of Record. Please cite this article as doi: $10.1111 /$ jssr.12258.

This article is protected by copyright. All rights reserved. 